\title{
ANALISIS FAKTOR-FAKTOR YANG MEMPENGARUHI TINGKAT PENDAPATAN PENDUDUK PENDATANG ASAL LUAR BALI SEBAGAI PEDAGANG KAKI LIMA DI KOTA DENPASAR
}

\author{
I Gede Made Yudi Antara' ${ }^{1}$ Lutfi Muta'ali², dan Wiwik Puji Mulyani
}

\author{
Fakultas Geografi, Universitas Gadjah Mada, Yogyakarta, Indonesia ${ }^{1,2,3}$ \\ igedemadeyudiantara@gmail.com
}

Diterima : Desember 2014 ; Direvisi : April 2015; Dipubikasikan: 30 September 2015

\begin{abstract}
ABSTRAK Sektor informal di perkotaan memicu pertumbuhan tenaga kerja yang tinggi. Keberadaan Pedagang Kaki Lima (PKL) dalam sektor informal telah mendominasi sektor lapangan pekerjaan di wilayah Kota Denpasar. Hal ini didorong oleh kurangnya pendapatan dan potensi keuntungan yang akan diperoleh di Kota Wisata Bali. Penelitian menggunakan metode quota sampling sebanyak 100 orang PKL secara purposif dengan pertimbangan yaitu jumlah penduduk terbesar, lokasi pusat perdagangan dan bisnis, dan keterjangkauan lokasi penelitian. Hasil penelitian menunjukkan sebagian PKL berusia 20-40 tahun dengan proporsi $75 \%$ adalah laki-laki. Sebanyak 73\% PKL telah tinggal di Denpasar selama kurang lebih 10 tahun. PKL yang datang ke Bali sebelumnya juga bekerja sebagai pedagang dengan pendidikan terakhir SMP/SMA. Rata-rata pendapatan bersih PKL sebesar Rp5.527.272,73,- per bulan telah layak diatas UMR tahun 2015 yaitu sebesar Rp 1.800.000,-. Kawasan wisata mempunyai pendapatan paling besar dibandingkan kawasan perdagangan dan bisnis. Umur, tingkat pendidikan, curahan jam kerja, lama usaha, modal, dan lokasi usaha mempunyai pengaruh positif terhadap pendapatan dengan nilai $R^{2}$ hasil regresi linier ganda sebesar 0,667 .
\end{abstract}

Kata kunci: Kota Denpasar; pedagang kaki lima; pendapatan.

\begin{abstract}
The informal sector in urban areas cause the growth of high labor. The existence of street vendors (PKL) in the informal sector has been dominated sector jobs in Denpasar region. It is driven by a lack of income and the potential benefits will be gained in tourism city of Bali. The study is using quota sampling of 100 people, purposively with consideration that populous center of trade and business location, and affordability study sites. The results shows that most vendors aged 20-40 years with proportion 75\% were male. As many as 73\% of PKL has lived in Denpasar for more than 10 years. Street vendors who come to Bali previously worked as a trader with the latest education junior high / high school. The average net income amounted Rp5.527.272,73 PKL, - every month have been worth over UMR 2015 was Rp 1.800.000, -. Tourist areas have the most revenue compared to the trade and business. Age, level of education, the outpouring of working hours, long effort, capital and business location has a positive impact on revenue to the value of $R 2$ result of multiple linear regression of 0.667 .
\end{abstract}

Key words: Denpasar city; street vendors; income.

\section{PENDAHULUAN}

Kota Denpasar sebagai pusat pertumbuhan ekonomi Provinsi Bali mendorong laju pertumbuhan penduduk (LPP) cukup tinggi. Jumlah penduduk migran di Kota Denpasar mencapai 415.417 jiwa, sedangkan jumlah penduduk non migran lebih sedikit dibandingkan dengan penduduk migran di Kota Denpasar yaitu sebesar 373.172 jiwa yang artinya penduduk pendatang (migrant) mendominasi wilayah Kota Denpasar (BPS Provinsi Bali, 2010).

Kehadiran sektor informal perkotaan dianggap sebagai salah satu sektor ekonomi yang muncul sebagai akibat dari situasi pertumbuhan tenaga kerja yang tinggi di kota. Keberadaan sektor informal memiliki daya serap terhadap tenaga kerja yang cukup besardan berperan sebagai sektor penyangga (buffer zone) yang sangat lentur dan terbuka, juga memiliki kaitan erat dengan jalur distribusi barang dan jasa ditingkat bawah, dan bahkan menjadi ujung tombak pemasaran yang potensial (Suyanto dan Karnaji, 2005 dalam Rolis, $\underline{2013})$.

Jenis usaha di sektor informal sebagai PKL (Pedagang Kaki Lima) banyak digeluti oleh penduduk pendatang di kota Denpasar karena metode tersebut karena dianggap lebih hemat dari segi biaya sewa dibandingkan dengan toko permanen. Berdasarkan latar belakang tersebut maka dapat dirumuskan pertanyaan penelitian sebagai berikut: 1) bagaimanakah karakteristik sosial demografi penduduk pendatang asal luar Bali sebagai PKL di Kota Denpasar?; 2) bagaimanakah tingkat dan perbandingan pendapatan penduduk pendatang asal luar Bali sebagai PKL berdasarkan lokasi usaha di Kota Denpasar ?; dan 3) faktor-faktor apakah yang mempengaruhi tingkat 
pendapatan penduduk pendatang asal luar Bali sebagai PKL di Kota Denpasar?

Terdapat hipotesis bahwa: 1. Umur, tingkat pendidikan, curahan jam kerja, lama usaha, modal usaha, lokasi usaha berpengaruh terhadap pendapatan PKL di Kota Denpasar 2. Terdapat perbedaan pendapatan PKL berdasarkan lokasi usaha (kawasan perdagangan dan bisnis, kawasan wisata, kawasan permukiman) dan rata-rata pendapatan PKL di kawasan pariwisata lebih tinggi dibandingkan kawasan permukiman dan perdagangan.

Migrasi Penduduk menurut Mantra (1978) merupakan bentuk mobilitas penduduk secara horizontal, atau sering disebut mobilitas penduduk geografi. Mobilitas penduduk yaitu gerak (movement) penduduk melintasi batas wilayah menuju ke wilayah lain dalam periode waktu tertentu. Menurut Todaro (1996) migrasi berkembang karena perbedaan antar pendapatan yang diharapkan dan yang terjadi di pedesaan dan di perkotaan. Anggapan yang mendasar adalah bahwa para migran tersebut memperhatikan berbagai kesempatan kerja yang tersedia bagi mereka dan memilih salah satu yang bisa memaksimumkan manfaat yang mereka harapkan dari bermigrasi tersebut. Manfaat-manfaat yang diharapakan ditentukan oleh perbedaan-perbedaan nyata antara kerja di desa dan di kota serta kemungkinan migrasi tersebut untuk mendapatkan kerja di kota.

Penelitan ini juga menggunakan landasan teori migrasi dari Mc. Gee, yang menyatakan bahwa dalam kaitannya dengan pertambahan penduduk kota, banyak penduduk yang hidup kepada keadaan sub-marginal, dengan keadaan fisik rumah yang sesak dan tidak layak. Pendapat Mc.Gee adalah didasarkan atas aspek superioritas kota dalam menyediakan peluang pekerjaan serta pendapatan bagi migran yang berasal dari kampung, karena adanya ciri ekonomi dualistik kota (Jalil, 2005).

Irawan dan Suparmoko (1981) dalam Hariningsih dan Simatupang (2008) berpendapat bahwa pendapatan seseorang adalah pendapatan yang telah diperoleh dari suatu kegiatan jenis usaha yang menghasilkan suatu keuntungan, hal ini sesuai dengan pendapatan yang diperoleh oleh PKL yaitu pendapatan yang diperoleh dari jenis usaha yang dilakukan yaitu usaha dagang sehingga memperoleh keuntungan yang disebut pendapatan.

Kasto (1995) menyatakan bahwa istilah sektor informal biasanya digunakan untuk menunjukkan sejumlah kegiatan ekonomi yang berskala kecil. Sektor informal merupakan manifestasi dari situasi pertumbuhan kesempatan kerja di negara yang sedang berkembang, untuk mencari kesempatan kerja daripada keuntungan. Pada umumnya mereka miskin, berpendidikan rendah, tidak terampil, dan umumnya migran.

Teori sektor informal pertama kali diperkenalkan Keith Harth, seorang antropolog Inggris dari Manchester University dalam penelitiannya yang berjudul Informal Income: Opportunities and Urban Employments in Ghana pada tahun 1971. Harth menggambarkan sektor informal sebagai angkatan kerja perkotaan (urban labour force),yang berada di luar pasaran tenaga kerja yang terorganisir dan teratur (Lamba, 2011). Harth, berdasarkan hasil pengamatannya membedakan kegiatan penduduk kota dalam memperoleh kesempatan kerja kedalam dua sektor yakni formal dan informal.

Menurut Evens \& Korff dalam Mustafa (2008) menyebutkan definisi mengenai PKL yaitu bagian dari sektor informal kota yang mengembangkan aktifitas produksi barang dan jasa di luar kontrol pemerintah dan tidak terdaftar. PKL merupakan kegiatan pokok ekonomi sektor informal di kota, maka Pemerintah Daerah diharapkan dapat mengkoordinasikan keberadaannya dalam struktur tata ruang kota dengan berpedoman pada Pasal pasal 28 Undang-undang RI Nomor 26 Tahun 2007 tentang Tata Ruang Kota disebutkan perencanaan tata ruang kota meliputi penyusunan, penepatan dan pengesahan rencana tata ruang kota dengan mempertimbangkan hal-hal sebagai berikut: 1) rencana penyediaan dan pemanfaatan ruang terbuka hijau; 2) rencana penyediaan dan pemanfaatan ruang terbuka non hijau; dan 3) rencana penyediaan dan pemanfaatan prasarana dan sarana jeringan pejalan kaki, angkutan umum, kegiatan sektor informal, dan ruang evakuasi bencana yang dibutuhkan untuk menjalankan fungsi wilayah kota sebagai pusat pelayanan sosial ekonomi dan pusat pertumbuhan wilayah.

\section{METODE PENELITIAN}

Penelitian ini akan dilakukan di Kota Denpasar, Provinsi Bali. Lokasi ini dipilih karena merupakan Ibu Kota dari Provinsi Bali yang merupakan pusat aktivitas ekonomi Provinsi Bali dengan tingkat kepadatan penduduk yang tinggi dan jumlah penduduk pendatang yang besar yang sebagian besar bermata pencaharian di sektor informal.Variabel penelitian ada 2 yaitu variable independent dan variable dependent variable independent yaitu Pendapatan penduduk pendatang sebagai PKL.Variabel Independent yaitu Alat dan Bahan beruapa Kuisioner, Peta pola ruang Kota Denpasar, Recorder, Kamera, Software SPSS 
Penelitian ini merupakan survei di Kota Denpasar teknik quota sampling sebanyak 100 orang PKL Penentuan responden secara purposif sehingga teknik penentuan sampel berdasarkan pertimbanganpertimbangan tertentu sehingga karakteristiknya dianggap cocok digunakan dalam penelitian. Oleh karena dipilih lokasi konsentrasi PKL di Kota Denpasar yang dijadikan sampel berdasarkan pertimbanganpertimbangan tertentu yaitu :

a) Kawasan Permukiman di Kelurahan Sesetan dan sekitarnya yang terletak di Denpasar Selatan dipilih menjadi lokasi penelitian terkait dengan PKL di kawasan permukiman, hal ini dikarenakan Kelurahan Sesetan memiliki jumlah penduduk paling besar dibandingkan dengan Kelurahan lain di wilayah Kota Denpasar yaitu sebesar 51.344 jiwa dan sebagian besar wilayahnya adalah berupa permukiman penduduk.

b) Kawasan perdagangan dan bisnis yang mengelompok berada di pusat Kota yaitu dipusatkan di Pasar Kreneng dan Pasar Badung, sehingga kawasan Pasar Kreneng dan Pasar Badung dipilih menjadi lokasi penelitian untuk PKL di kawasan perdagangan dan bisnis.

c) Lokasi penelitian untuk kawasan yang dipilih adalah kawasan wisata Sanur karena mempunyai posisi yang sangat strategis, mudah dijangkau dari segala arah, dengan kendaraan umum dan merupakan salah satu kawasanyang dikembangkan menjadi kawasan wisata nasional dan internasonal.

Dalam menganalisis hasil penelitan dijelaskan sebagai berikut:

1. Permasalahan pertama yaitu mengenai karakterstik demografi dan sosial ekonomi PKL dianalisis dengan analisis statistik deskriptif yang digunakan untuk menyajikan dan menganalisis data agar lebih lebih bermakna dan komunikatif dan disertai perhitungan-perhitungan sederhana yang bersifat lebih memperjelas keadaan dan atau karakteristik data yang digunakan.

2. Permasalahan kedua yaitu mengenai tingkat dan perbandingan pendapatan berdasarkan lokasi usaha dianalisis dengan dengan analisis satatistik deskriptifdan inferensial yaitu dengan teknik analisis statistikOne Way Anova karena dilakukan uji beda lebih dari dua sampel.

3. Permasalahan ketiga dianalisis dengan teknik analisis statistik regresi linier berganda untuk mengetahui pengaruh umur, jenis kelamin, tingkat pendidikan, jam kerja, lama usaha, modal usaha, lokasi usaha terhadap tingkat pendapatan penduduk pendatang di sektor informal sebagai PKL.

\section{HASIL DAN PEMBAHASAN}

Karakteristik demografi yang dimaksud adalah ciriciri yang menggambarkan perbedaan masyarakat dalam hal ini adalah dilihat berdasarkan umur, jumlah anggota keluarga dan lama migrasi migrasi di Kota Denpasar. Berdasarkan data yang diperoleh dapat dilihat bahwa sebagian besar penduduk pendatang yang bekerja sebagai PKL adalah berumur 20-30 tahun dan 31-40 tahun yaitu masing-masing sebesar $33,3 \%$ dan paling kecil adalah berumur diatas 50 tahun. Menurut jumlah anggota keluarga yang menjadi tanggungan menunjukkan penduduk pendatang yang bermata pencaharian sebagai PKL di Kota Denpasar rata-rata memiliki jumlah anggota keluarga 3-4 orang yaitu sebesar 54\%. Berdasarkan lama tinggal di Kota Denpasar dapat diketahui bahwa pendatang asal luar bali sebagai PKL di Kota Denpasar sebagian besar atau sebesar 73\% baru tinggal di Kota Denpasar selama 1-10 tahun.

Pada pembahasan berikutnya akan dibahas mengenai karakteristik penduduk pendatang sebagai PKL di Kota Denpasar berdasarkan ciri-ciri sosial ekonomi seperti tingkat pendidikan, pekerjaan sebelumnya di daerah asal dan status tempat tinggal di Kota Denpasar. Berdasarkan data yang diperoleh dapat dilihat bahwa sebesar 34\% PKL di Kota Denpasar berpendidikan SMP dan SMA, sebesar 29\% berpendidikan SD dan hanya 3\% yang tidak bersekolah. Berdasarkan pekerjaan sebelumnya di daerah asal dapat diketahui bahwa sebesar $27 \%$ penduduk pendatang asal luar Bali sebagai PKL di Kota Denpasar sebelumnya bekerja sebagai petani/nelayan di daerah asal, sebesar $26 \%$ sebagai pedagang, $9 \%$ sebagai pegawai dan sebesar $21 \%$ tidak bekerja. Karakteristik menurut tempat tinggal menunjukkan bahwa sebesar $46 \%$ penduduk pendatang sebagai PKL di Kota Denpasar dengan status tempat tinggal kontrak, 44\% menyewa kamar atau kos, 6\% menumpang dengan teman/kerabat atau saudara dan hanya $4 \%$ mempunyai tempat tinggal yang berstatus milik sendiri.

Berdasarkan penjelasan sebelumnya mengenai ratarata pendapatan bersih perhari yang diperoleh oleh PKL di Kota Denpasar, diketahui bahwa 56\% penduduk pendatang asal luar Bali sebagai PKL memperoleh penghasilan antara Rp3000.000 hingga Rp6000.000 perbulan, sebesar $36 \%$ memperoleh penghasilan diatas Rp6000.000 perbulan dan 8\% PKL di Kota Denpasar memperoleh penghasilan Rp3000.000 perbulan. Memperhatikan Upah Minimum Regional (UMR) Kota Denpasar tahun 2015 yaitu sebesar Rp1.800.000, yang ditetapkan berdasarkan survei Kehidupan Hidup Layak 
(KHL) pada Desember Tahun 2014 yaitu sebesar Rp1792.608, maka dapat disimpulkan bahwa rata-rata pendapatan PKL di Kota Denpasar sudah jauh melebihi UMR Kota Denpasar.

Berdasarkan Tabel 1 dapat diketahui bahwa penduduk pendatang asal luar Bali sebagai PKL di kawasan permukiman Kota Denpasar rata-rata berpendapatan sebesar Rp5.527.272,73 perbulan, PKL di kawasan perdagangan rata-rata berpendapatan Rp5.294.117,65 per bulan dan PKL pada kawasan wisata rata-rata berpendapatan $\mathrm{Rp} 8.454 .545,45$ per bulan. Berdasarkan nilai probabilitas yang disajikan dalam tabel yaitu diperoleh nilai signifikansi $<0,05$ jadi dapat disimpulkan bahwa terdapat perbedaan yang bermakna dari rata-rata pendapatan PKL berdasarkan lokasi usaha di Kota Denpasar. Hal ini juga menunjukkan bahwa PKL di kawasan pariwisata memanfaatkan fungsi kawasan dengan baik, kawasan pariwisata di Kota Denpasar memiliki aktifitas pariwisata yang tinggi sehingga PKL dikawasan ini menyesuaikan atau memanfaatkan dengan menambah jam kerja sehingga mampu mendapat pendapatan yang lebih tinggi.

Berdasarkan analisis yang dilakukan dengan tujuan untuk mengetahui faktor-faktor yang mempengaruhi pendapatan PKL di Kota Denpasar, maka dapat diketahui pengaruh dari variabel-variabel seperti umur, tingkat pendidikan, curahan jam kerja, lama usaha, modal usaha dan lokasi yang diposisikan sebagai variabel pengaruh (independent) terhadap tingkat pendapatan PKL sebagai variabel terpengaruh (dependent). Hasil analisis menunjukkan bahwa terdapat pengaruh yang signifikan secara bersama-sama atau simultan antara variabel bebas yaitu umur, tingkat pendidikan, curahan jam kerja, lama usaha dan modal usaha terhadap variabel terikat yaitu pendapatan PKL di Kota Denpasar.

Analisis secara parsial mengenai pengaruh dari masing-masing variabel bebas terhadap variabel terikat adalah bahwa terdapat pengaruh dari variabel tingkat pendidikan, curahan jam kerja, modal usaha dan lokasi usaha secara parsial terhadap variabel pendapatan. Sedangkan variabel yang tidak mempunyai pengaruh secara parsial terhadap variabel pendapatan PKL adalah variabel umur dan lama usaha.

Berdasarkan hasil analisis regresi linier ganda yang telah dilakukan, diperloleh nilai $R^{2}$ sebesar 0,667 , hal ini berarti bahwa pengaruh dari variabel bebas yaitu umur, tingkat pendidikan, curahan jam kerja, lama usaha, modal dan lokasi usaha terhadap pendapatan penduduk pendatang sebagai PKL di Kota Denpasar adalah sebesar $66,7 \%$ sehingga sebesar 33,3 \% dijelaskan oleh variabel lain diluar variabel bebas yang digunakan dalam penelitian.

Tabel 1. Hasil Analisis Menggunakan Uji Statistik One Way Anova

\begin{tabular}{lcc}
\hline \multicolumn{1}{c}{ Lokasi } & Nilai rata-rata (Mean) & Nilai Signifikansi (Sig) \\
\hline Kawasan Permukinan & 5527272.73 & 0.000 \\
Kawasan Perdagangan & 5294117.65 & \\
Kawasan Wisata & 8454545.45 & \\
\hline
\end{tabular}

Sumber : Analisis Data Primer dengan SPSS

\section{KESIMPULAN}

1. PKL di Kota Denpasar sebagian besar PKL berusia 20-40 tahun, 75\% PKL adalah laki-laki. Sebesar 81\% sudah menikah dengan rata-rata jumlah anggota keluarga 3-4 orang. PKL asal luar Bali sebagian besar baru tinggal di Kota Denpasar selama 1-10 tahun. PKL di Kota Denpasar rata-rata berpendidikan SMP-SMA dan sebagian besar memiliki status tempat tinggal mengontrak. Pekerjaan PKL sebelumnya di daerah asal paling banyak adalah sebagai petani/nelayan.

2. PKL di Kota Denpasar memiliki pendapatan perbulan yaitu antara Rp3000.000 hingga Rp6000.000 perbulan yaitu sebesar 56\%. PKL kawasan permukiman Kota Denpasar rata-rata berpendapatan sebesar Rp5.527.272,73 per bulan, PKL di kawasan perdagangan rata-rata berpendapatan Rp5.294.117,65 perbulan dan PKL pada kawasan wisata rata-rata berpendapatan Rp8.454.545,45 perbulan. Terdapat perbedaan yang bermakna dari rata-rata pendapatan PKL di Kota Denpasar berdasarkan lokasi usaha, dan PKL pada kawasan pariwisata memperoleh pendapatan ratarata perbulan paling tinggi dibandingkan dengan PKL di kawasan permukiman dan PKL di kawasan perdagangan.

3. Terdapat pengaruh yang signifikan secara simultan antara variabel bebas yaitu umur, tingkat pendidikan, curahan jam kerja, lama usaha, modal usaha dan lokasi usaha terhadap pendapatan PKL di Kota Denpasar. Sedangkan secara parsial terdapat pengaruh dari variabel tingkat pendidikan, curahan jam kerja, modal usaha dan lokasi usaha terhadap variabel pendapatan.

\section{DAFTAR PUSTAKA}


Hariningsih, Endang dan Simatupang. (2008). FaktorFaktor yang Mempengaruhi Kinerja Usaha Pedagang Eceran (Studi Kasus: Pedagang Kaki Lima di Kota Yogyakarta). Jurnal Bisnis dan Manajemen. 4(2). Universitas Andalas.

Kasto. (1995). Konsep dan Pengukuran Ketenagakerjaan. Paper disampaikan pada pelatihan Mobilitas Penduduk 11-23 Desember. Yogyakarta. Pusat Studi Kependudukan, Universitas Gadjah Mada.

Lamba, Arung. (2011). Kondisi Sektor Informal Perkotaan dalam Perekonomian Jayapura-Papua. Jurnal Ekonomi Bisnis, No.2. Fakultas Ekonomi Universitas Cenderawasih.

Mantra, Ida Bagoes. (1978). Population Movement in Wet-Rice Communities : a Study of Two Dukuhs in
Yogyakarta Special Region. Phd. Thesis. University of Hawaii, Honolulu. Unpublished.

Mustafa. A, Ali. (2008). Model Transformasi Sosial Sektor Informal: Sejarah, Teori dan Praksis PKL. Malang. INSPIRE.

Rolis, Ilyas, (2013). Sektor Informal dan Ikhtiar Pemberdayaannya. Fakultas Dakwah dan Ilmu Komunikasi IAIN Sunan Ampel Surabaya. Jurnal Sosiologi Islam. 3(2).

Todaro, Michael P. (1996). Kajian Ekonomi Migrasi Internal di Negara Berkembang, Yogyakarta. Pusat Penelitian Kependudukan UGM.

Undang-Undang RI Nomor 26 Tahun 2007 tentang Tata Ruang Kota.

Yunus, Hadi Sabari. (2000). Struktur Tata Ruang Kota. Yogyakarta. Pustaka Pelajar. 